\begin{tabular}{|c|c|c|}
\hline Postgraduate Bosowa University Publishing (PBUP) & $\begin{array}{c}\text { INDONESIAN } \\
\text { JOURNAL }\end{array}$ \\
\hline Indonesian Journal of Business and Management & e-ISSN: $2460-3767 \quad p$-ISSN: $2656-6885$ & OF BUSINESS \\
\hline
\end{tabular}

\title{
PENGARUH KUALITAS LAYANAN TERHADAP LOYALITAS PELANGGAN PADA LEMBAGA PENYIARAN PUBLIK RADIO REPUBLIK INDONESIA MAKASSAR
}

\author{
The Influence of Service Quality on Customer Loyalty in the Public Broadcasting Institution Radio of the \\ Republic of Indonesia, Makassar
}

\author{
Nurhikmah Amalia Ramli ${ }^{1}$, Hasanuddin Remmang ${ }^{2}$, Muhlis Ruslan² \\ ${ }^{1}$ Mahasiswa Magister Manajemen Universitas Universitas Bosowa \\ ${ }^{2}$ Program Studi Manajemen Program Pascasarjana Universitas Bosowa \\ Email: hkmhar13@gmail.com
}

Diterima: 22 Januari 2020/Disetujui: 05 Juni 2020

\begin{abstract}
ABSTRAK
Penelitian ini bertujuan untuk mengetahui pengaruh kualitas pelayanan (bukti fisik, kehandalan, daya tanggap, jaminan, dan empati) terhadap loyalitas pelanggan yang dimana dalam hal ini adalah pendengar Radio Republik Indonesia Makassar. Metode penelitian yang digunakan adalah teknik non random sampling dengan menggunakan klaster sampling acak sebanyak 100 orang pendengar radio RRI. Hasil penelitian menunjukkan bahwa variabel keandalan memiliki pengaruh yang signifikan yang artinya siaran RRI Makassar konsisten dalam ketepatan siaran, keakuratan infomasi dan tepat waktu. Ketika menyiarkan program siaran, variabel daya tanggap memilik pengaruh yang signifikan kepada pendengar dalam bentuk layanan seperti menanggapi dan memberikan solusi kepada pendengar saat penyiaran maupun masalah-masalah yang disampaikan oleh pendengar ke penyiaran atau ke RRI Makassar. Variabel jaminan berpengaruh signifikan yang artinya jaminan yang telah diberikan oleh RRI Makassar telah memberikan kenyaman dalam mendengar dan melayani para pendengar radio RRI Makassar. Variabel empati berpengaruh signifikan artinya empati penyiar dan RRI makassar sudah peka terhadap keinginan dan kebutuhan pendengar. Begitupula dengan variabel bukti fisik memiliki pengaruh yang signifikan yang berarti menunjang siaran RRI Makassar sudah baik seperti alat pendukung siaran yang membuat frekuenzi dan suara penyiar jelas Ketika didengar.
\end{abstract}

Kata Kunci: Kualitas Pelayanan, Bukti Fisik, Empati, Daya Tanggap, Kehandalan, Jaminan, Loyalitas Pelanggan

\begin{abstract}
This study aims to study the effect of service quality (physical evidence, reliability, responsiveness, assurance, and empathy) on customer loyalty which in this case was the listener of Radio Republik Indonesia, Makassar. The research method used was a non-random sampling technique using a random cluster sampling of 100 RRI radio listeners. The results showed that the reliability variable had a significant effect, which means that RRI Makassar broadcasts were consistent in broadcasting accuracy, information accuracy, and on time. When broadcasting broadcast programs. The responsiveness variable had a significant effect on listeners in the form of services such as responding and providing solutions to listeners when broadcasting, as well as problems conveyed by listeners to the broadcasting or to RRI Makassar. The assurance variable had a significant effect, which means that the assurance provided by RRI Makassar had provided comfort in hearing and serving listeners of RRI Makassar. The empathy variable had a significant effect, meaning the broadcaster's empathy and RRI Makassar was already sensitive to the wants and needs of listeners. Also, the physical evidence variables had a significant effect, which means that supporting RRI Makassar broadcasts was good, such as broadcast support tools that made frequency and the announcer's voice was clearly heard.
\end{abstract}

Keywords: Service Quality, Physical Evidence, Empathy, Responsiveness, Reliability, Assurance, Customer Loyalty 


\section{PENDAHULUAN}

Mengelola bisnis di media penyiaran merupakan salah satu yang paling sulit dan paling menantang dibandingkan dengan jenis industry lainnya. Mengelola media penyiaran pada dasarnya adalah mengelola manusia. Keberhasilan media penyiaran sejatinya ditopang oleh kreatifitas manusia dalam bekerja pada tiga pilar utama yang merupakan fungsi vital yang dimiliki setiap media penyiaran yaitu teknik, program dan pemasaran. Penggunaan radio dalam masa sebelum perang adalah penggembangan pendeteksian pesawat dan kapal dengan penggunaan radar. Sekarang ini fungsi dari radio banyak bentuknya, termasuk jaringan tanpa kabel, komunikasi bergerak di segala jenis dan juga penyiaran radio. Radio memiliki beberapa kekuatan karena dapat menjangkau jumlah khayalak sasaran yang besar pada waktu yang bersamaan, cepat menyampaikan pesan sehingga dapat memberikan informasi yang paling mutakhir dan mudah dimengerti, juga memberikan bentuk hiburan yang menarik. Persaingan didunia radio sekarang termasuk yang mengalami perkembangan terlihat dari banyaknya radio - radio yang muncul dan membuat ketatnya persaingan antar radio.

Lembaga Penyiaran Publik Radio Republik Indonesia (LPP RRI) merupakan sebuah lembaga yang bertujuan menyampaikan berita, hiburan, iklan yang ditujukan kepada masyarakat. Fokus utamanya adalah pelayanan dalam bentuk penyiaran informasi khususnya melalui gelombang radio. RRI adalah satu-satunya radio yang menyandang nama negara yang siarannya ditujukan untuk kepentingan bangsa dan negara. RRI tidak hanya hadir di Kota Makassar saja tetapi di seluruh Provinsi Sulawesi Selatan, RRI mempunyai Stasiun relay dan juga pemancar Relay dengan jangkauan yang luas sehingga dapat menjangkau masyarakat di Provinsi Sulawesi Selatan. Tuntutan pelayanan terbaik dan maksimal membuat tugas-tugas yang diberikan kepada karyawan semakin berat dan banyak.

Loyalitas konsumen adalah keadaan yang menunjukkan loyalnya seseorang konsumen pada suatu objek tertentu. Menurut Giddens (2002) dan Fajar et al. (2020) loyalitas pelaggan adalah salah satu variable yang sangat penting karena loyalitas pelanggan secara positif mempengaruhi berkembangnya suatu lembaga public penyiaran. Konsumen membandingkan persepsi mereka atas kualitas suatu produk ataupun layanannya setelah menggunakan jasa tersebut sesuai dengan ekspektasi produk sebelum mereka membelinya. Salah satu faktor yang dapat mempengaruhi loyalitas pelanggan adalah kualitas pelayanan. Kualitas dalam sebuah pelayanan merupakan kondisi dinamis yang berhubungan dengan produk, jasa, manusia, proses, dan lingkungan yang memenuhi atau melebihi harapan (Tjiptono,2002). Membagi kualitas pelayanan menjadi lima dimensi pokok utama yang terdiri dari keandalan, ketanggapan, jaminan, empati, dan bukti fisik.

Lembaga radio harus meningkatkan inovasi dan terus berkreatifitas dalam meningkatkan kualitasnya baik itu dari segi pelayanan maupun kualitas program siaran seperti menghadirkan narasumber-narasumer, menyajikan informasi yang terpercaya dan tidak bersifat bohong atau isu sara, dan menyajikan hiburan yang dapat dinikmati dari semua kalangan usia. Bagaimana agar lembaga radio memberikan inovasi dan kreatifitasnya agar masyarakat di kota tidak hanya di daerah juga tetap mendengarkan radio. Dalam hal ini juga menjadi tantangan tersendiri untuk RRI sebagai Lembaga Penyiaran Publik yang independen, netral dan tidak komersial yang berfungsi memberikan pelayanan siaran informasi, pendidikan, hiburan yang sehat, kontrol sosial, serta menjaga citra positif bangsa di dunia internasional. Dalam industri jasa khususnya dalam bidang radio semakin banyaknya radio swasta yang terus hadir memberikan kualitas layanan yang terbaik untuk konsumennya. Karena tidak adanya visual yang dapat dilihat oleh konsumennya, maka lembaga harus berinovasi bagaimana pendengar dapat menikmati program acara yang dihadirkan walaupun hanya melalui suara. Atau perusahaan harus memiliki inovasi terbaru yaitu mendengarkan radio bisa sambil melihat visualnya. Jadi para pendengarnya tidak hanya mendengarkan tapi juga dapat melihat penyiar radionya melalui web streaming.

Berdasarkan latar belakang masalah di atas dan melihat pentingnya kualitas layanan dan Loyalitas Konsumen terhadap lembaga penyiaran radio, maka perlu dilakukan penelitian dengan pengaruh kualitas layanan terhadap loyalitas konsumen Radio Republik Indonesia Makassar “.

\section{METODE}

\subsection{Jenis Penelitian}

Jenis penelitian ini adalah penelitian kuantitatif. Metode penelitian kuantitatif merupakan salah satu jenis penelitian yang spesifikasinya adalah sistematis, terencana dan terstruktur dengan jelas sejak awal hingga pembuatan desain penelitiannya. Metode penelitian kuantitatif, sebagaimana dikemukakan oleh Sugiyono (2016) yaitu metode penelitian yang berlandaskan pada filsafat positivisme, digunakan untuk meneliti pada populasi atau sampel tertentu, pengumpulan data menggunakan instrumen penelitian, analisis data bersifat kuantitatif/statistik, dengan tujuan untuk menguji hipotesis yang telah ditetapkan

\subsection{Lokasi dan Jadwal Penelitian}

Penelitian ini akan dilakukan di Radio Republik Indonesia Makassar yang terletak di Jl. Riburane No.3 Makassar.

\subsection{Populasi dan Sampel}

Populasi adalah wilayah generalisasi yang terdiri atas objek atau subjek yang mempunyai kualitas dan karakteristik tertentu yang ditetapkan oleh penelitian untuk dipelajari dan ditarik kesimpulannya (Sugiyono, 2013). Populasi dalam penelitian ini adalah pendengar Radio Republik Indonesia Makassar. Dalam penelitian ini diketahui total responden pendengar per programa Radio Republik Indonesia Makassar perbulaannya yang terdapat 
pada web http;/puslitbangdiklatrri.co.id adalah sebesar 11.780 orang.

Sampel merupakan bagian dari jumlah karakteristik yang dimiliki oleh populasi (Sugiyono, 2012). Dalam penelitian ini rumus yang digunakan untuk mengukur sampel adalah rumus slovin (Darmawan, 2013). Dalam penelitian ini, peneliti menggunakan teknik simple random sampling. Ialah pengambilan anggota sample dari populasi yang dilakukan secara acak tanpa memperhatikan strata yang ada adalam populasi itu. Teknik random sampling ini memberikan hak yang sama kepada setiap subjek populasi untuk memperoleh kesempatan dipilih menjadi sample (Sugiyono, 2013).

Populasi dalam penelitian ini adalah 11.780 orang dengan taraf kesalahan sebesar $10 \%$ dan taraf kepercayaan sebesar 95\%. Berikut rumus yang digunakan:

$$
\mathrm{n}=\mathrm{N}(1+\mathrm{Ne} 2)
$$

Keterangan:

$\mathrm{n}=$ Ukuran Sampel

$\mathrm{N}=$ Ukuran Populasi

$\mathrm{e}=$ Persentase kelonggaran ketidaktelitian (10\%)

Dalam menciptakan populasi (N), dilakukan perhitungan menggunakan rata-rata. Berdasarkan rumus Slovin diatas, maka ukuran sampel dalam penelitian ini sebagai berikut:

$$
\begin{aligned}
\mathrm{n} & =11780(1+(11780.0,12) \\
& =11780(1+(11780.0,01) \\
& =11780(1+(117.8) \\
& =11.854 / 118.8 \\
& =99,15
\end{aligned}
$$

\subsection{Variabel Penelitian}

Variabel dalam penelitian ini dibagi menjadi dua, yaitu: Variabel Bebas yang ini meliputi a. Keandalan (X1), b. Daya Tanggap (X2), c. Jaminan (X3), d. Empati (X4), dan e. Bukti Fisik (X5). Sedangkan Variabel Terikat (Y) yang digunakan dalam penelitian ini adalah Loyalitas pelanggan.

\subsection{Teknik Pengumpulan Data}

Teknik pengumpulan data merupakan cara-cara yang dilakukan untuk memperoleh data dan keteranganketerangan yang diperlukan dalam penelitian. Peneliti melakukan pengumpulan data dan dilengkapi oleh berbagai keterangan melalui Penelitian Lapangan (Field Research) yang merupakan cara untuk memperoleh data primer yang secara langsung melibatkan pihak responden dan dijadikan sampel dalam penelitian. Metode penelitian lapangan yang digunakan peneliti adalah sebagai berikut:

a. Observasi. Peneliti terlebih dahulu menentukan tempat penelitian dan melakukan survey terhadap tempat dalam hal penelitian ini yaitu pada Lembaga Penyiaran Publik Radio Republik Indonesia.

b. Kuesioner. Kuesioner merupakan teknik pengumpulan data yang dilakukan dengan cara memberi seperangkat pertanyaan atau pernyataan tertulis kepada responden untuk dijawabnya. Kuesioner merupakan teknik pengumpulan data dengan tujuan untuk memperoleh informasiinformasi yang relevan mengenai variabel-variabel penelitian yang akan diukur dalam penelitian ini.

c. Studi Kepustakaan (Library Research). Dalam studi kepustakaan ini penulis mengumpulkan dan mempelajari berbagai teori dan konsep dasar yang berhubungan dengan masalah yang diteliti. Teori dan konsep dasar tersebut peneliti peroleh dengan cara menelaah berbagai macam sumber seperti buku, jurnal, dan bahan bacaan yang relevan.

d. Riset Internet (Online Riset). Tenik pengumpulan data yang berasal dari situs-situs atau website yang berhubungan dengan berbagai informasi yang dibutuhkan dalam penelitian.

\subsection{Jenis dan Sumber Data}

Jenis data yang digunakan dalam penelitian ini adalah :

a. Data Kualitatif, yaitu data yang diperoleh dari Lembaga Penyiaran Publik Radio Republik Indonesia dalam bentuk informasi baik secara lisan maupun secara tulisan.

b. Data kuantitatif adalah jenis data yang dapat diukur atau dihitung secara langsung, yang berupa informasi atau penjelasan yang dinyatakan dengan bilangan atau berbentuk angka. Dalam penelitian ini data kuantitatif yang diperlukan adalah : Jumlah Responden hasil Pendengar dan hasil angket.

Sedangkan sumber data yang digunakan dalam penelitian ini adalah :

a. Data Primer

Data primer adalah data yang didapat dari sumber pertama baik dari individu atau perseorangan, seperti hasil wawancara atau hasil pengsisian kuesioner.

b. Data Sekunder

Data sekunder adalah data primer yang telah diolah lebih lanjut dan disajikan baik oleh pihak pengumpul data primer atau oleh pihak lain. Data sekunder disajikan antara lain dalam bentuk tabel-tabel atau diagram-diagram.

\subsection{Analisis Data}

Dari hasil penelitian yang dikumpulkan maka selanjutnya akan dapat disajikan analisis terhadap masalah yang dihadapi dengan menggunakan analisis kuantitatif yaitu sebagai berikut:

\section{a. Uji Instrumen}

1) Uji validitas digunakan untuk mengetahui valid atau tidaknya suatu kuesioner. Suatu kuesioner dikatakan valid jika pertanyaan pada kuesioner mampu mengungkapkan sesuatu yang akan diukur oleh kuesioner tersebut. Uji validitas dilakukan dengan membandingkan nilai $r$ hitung dengan nilai $r$ variabel untuk degree of freedom $(\mathrm{df})=\mathrm{n}-2$ dengan alpha 0,05. Jika rhitung lebih besar dari rtabel dan nilai $r$ positif, maka butir atau pertanyaan tersebut dikatakan valid.

2) Uji Reliabilitas dalam penelitian ini dilakukan dengan cara mencobakan instrumen sekali saja, dan 
dari data yang diperoleh dianalisis dengan teknik tertentu. Teknik reliabilitas semacam ini disebut internal consistency. Dikarenakan dalam penelitian ini jawaban dari instrumen bersifat berjenjang atau tidak bersifat dikotomi (mempunyai dua alternatif jawaban) maka digunakan teknik pengujian dengan metode Alpha Cronbach. Dalam melakukan perhitungan Alpha Cronbach digunakan alat bantu program komputer SPSS for Windows 7 dengan menggunakan model Alpha.

b. Analisis Regresi Berganda

Sugiyono (2016) menyatakan bahwa analisis yang digunakan peneliti, bila bermaksud meramalkan bagaimana keadaan (naik turunnya) variabel dependen (kriterium), bila dua atau lebih variabel independen sebagai faktor prediktor dimanipulasi (dinaik turunkan nilainya) dengan rumus:

$$
\mathrm{Y}=\alpha+\beta 1 \mathrm{X} 1+\beta 2 \mathrm{X} 2+\beta 3 \mathrm{X} 3+\mathrm{e}
$$

Keterangan:

$\mathrm{Y}=$ Loyalitas Pelanggan

$\mathrm{A}=$ Konstanta

$\beta 1-\beta 5=$ Koefisien regresi berganda

$\mathrm{X} 1=$ Keandalan

$\mathrm{X} 2=$ Ketanggapan

$\mathrm{X} 3=$ Jaminan

$\mathrm{X} 4=$ Empati

$\mathrm{X} 5=$ Bukti fisik

$\mathrm{E}=$ Standard error

c. Uji Hipotesis

1) Uji Parsial (Uji T)

Menurut Ghozali (2018) bahwa untuk menguji apakah variabel bebas mempunyai pengaruh secara parsial terhadap variabel terikat, maka digunakan uji parsial (uji t). Apabila dari perhitungan diperoleh probabilitas $<0,05$, maka dapat dikatakan bahwa variabel keandalahn, daya tanggap, jaminan, empati dan bukti fisik terrhadap loyalitas konsumen Menentukan koefisien determinasi ( r2). Menurut Ghozali (2018) Koefisien determinasi parsial (r2) digunakan untuk mengetahui besarnya sumbang atau kontribusi yang diberikan oleh variabel bebas terhadap variabel terikat secara parsial. Koefisien ini menunjukan seberapa besar variasi variabel independen digunakan dalam model mampu menjelaskan variasi variabel dependen.

2) Uji Simultan (Uji F)

Menurut Ghozali (2018). Untuk menguji apakah variabel bebas mempunyai pengaruh secara simultan atau secara bersama-sama terhadap variabel terikat, maka digunakan uji F. Apabila dari perhitungan diperoleh probabilitas $<0,05$, maka dapat dikatakan bahwa variabel keandalan, daya tanggap, jaminan, empati dan bukti fisik terrhadap loyalitas konsumen secara simultan.

\section{HASIL DAN PEMBAHASAN}

Lembaga penyiaran radio diperlukan manajemen penyiaran yang dapat menjawab tuntutan dan harapan masyarakat terhadap Lembaga Penyiaran Publik (LPP) RRI Makassar dalam memasuki persaingan antar media yang semakin kompetitif. Tidak hanya memberikan layanan yang memuaskan pada pendengarnya, tetapi dibutuhkan juga kualitas pelayanan yang lebih baik. Kualitas memberikan suatu dorongan kepada pendengar untuk menjalin ikatan yang kuat dengan lembaga penyiaran, dalam jangka panjang ikatan seperti ini dapat memungkinkan suatu lembaga penyiaran untuk memahami dengan seksama harapan yang bagaimana yang diharapkan oleh pendengar untuk terciptanya Loyalitas Konsumen.

Upaya dari stasiun radio terhadap konsumen di Kota Makassar dipengerahi oleh jumlah penduduk Kota Makassar yang besar yaitu 1.526.677 jiwa berdasarkan data Badan Pusat Statistik (BPS) pada tahun 2019 sehingga menjadikan kebutuhan akan media massa khususnya stasiun radio sebagai sarana informasi juga terus meningkat. Sebagai informasi awal daftar-daftar Radio di Kota Makassar Sebagai Berikut:

Tabel 1. Daftar Radio Di kota Makassar

\begin{tabular}{|c|c|c|}
\hline No & Nama Perusahaan & Nama Udara \\
\hline 1 & $\begin{array}{l}\text { PT Radio Al- Ikhwan Studio Tamasa } \\
\text { (FM } 101,90 \mathrm{Mhz} \text { ) }\end{array}$ & Al Ikhwan FM \\
\hline 2 & $\begin{array}{l}\text { PT Radio Bayuresha (FM 105,10 } \\
\text { Mhz) }\end{array}$ & Prambors Rasisonia \\
\hline 3 & $\begin{array}{l}\text { PT Radio Bharata Rasihima (FM } \\
95,20 \mathrm{Mhz} \text { ) }\end{array}$ & Radio Bharata FM \\
\hline 4 & $\begin{array}{l}\text { PT Radio Forum Madama (FM 87,70 } \\
\text { Mhz) }\end{array}$ & Radio Madama \\
\hline 5 & $\begin{array}{l}\text { PT Radio Gamasi Jaya (FM 105,90 } \\
\text { Mhz) }\end{array}$ & Gamasi FM \\
\hline 6 & $\begin{array}{l}\text { PT Radio Makassar Cipta Perdana } \\
\text { (FM 99,20 Mhz }\end{array}$ & Delta FM \\
\hline 7 & $\begin{array}{l}\text { PT Radio Suara Mercurius Kencana } \\
\text { (FM 104,20 Mhz) }\end{array}$ & Merkurius Top FM \\
\hline 8 & $\begin{array}{l}\text { PT Radio Suara Sentosa Pratama } \\
\text { (FM 103,4 Mhz) }\end{array}$ & SP FM \\
\hline 9 & $\begin{array}{l}\text { PT Radio Suara Sonata (FM 96,00 } \\
\text { Mhz) }\end{array}$ & Sonata FM / I Radio \\
\hline 10 & $\begin{array}{l}\text { PT Radio Swara Cristy Ria (Am } 828 \\
\text { Khz) }\end{array}$ & Radio Cristy \\
\hline 11 & $\begin{array}{l}\text { PT Radio Swara Makassar Artatiara } \\
\text { (FM 101,10 Mhz) }\end{array}$ & Smart FM \\
\hline 12 & $\begin{array}{l}\text { PT Radio Terminal Suara Lestari } \\
\text { (FM } 102,70 \mathrm{Mhz} \text { ) }\end{array}$ & $\begin{array}{l}\text { Telstar Pesona } \\
\text { Keluarga FM }\end{array}$ \\
\hline 13 & $\begin{array}{l}\text { PT Radio Venus Nusantara (FM } \\
97,60 \mathrm{Mhz} \text { ) }\end{array}$ & $\begin{array}{l}\text { Citra Musik Indonesia } \\
\text { / Venus FM }\end{array}$ \\
\hline 14 & $\begin{array}{l}\text { PT Radio Fajar Makassar (FM 89,3 } \\
\text { Mhz) }\end{array}$ & Fajar FM \\
\hline 15 & PT Suara Media (90,1 FM ) & Medika FM \\
\hline 16 & Radio Suara Celebes $(90,9$ FM & $\begin{array}{c}\text { Radio Suara Celebes } \\
\text { FM }\end{array}$ \\
\hline 17 & Syiar Fm $(107,1$ FM $)$ & Syiar FM Radio \\
\hline 18 & - & $\begin{array}{c}\text { Savana FM Makassar } \\
(106,5 \text { FM })\end{array}$ \\
\hline 19 & Radio Republik Indonesia (RRI) & RRI \\
\hline 20 & $\begin{array}{l}\text { PT Radio Galaxy Makassar FM } \\
(98,40 \mathrm{Mhz})\end{array}$ & Makassar FM \\
\hline
\end{tabular}


Banyaknya jumlah stasiun radio di kota Makassar ini, menggambarkan ketatnya kompetisi dalam bisnis penyiaran radio di kota Makassar untuk mendapatkan pangsa pasar yang besar dengan konsumen yang loyal, yang disebut sebagai pendengar aktif dan pendengar pasif. Selain fungsinya untuk hiburan, banyaknya media penyiaran di Kota Makassar tentunya memberikan kesempatan dalam memberikan informasi, terutama informasi yang diperlukan dan penting bagi masyarakat maupun juga informasi untuk kemajuan pembangunan Kota Makassar.

Beberapa tipe pendengar, pertama pendengar aktif yang mempunyai keterlibatan langsung dengan acara, mempunyai komunikasi langsung atau tidak langsung dengan penyiar/radio, interaksi aktif dalam talkshow maupun dialog, kirim salam melalui berbagai media baik itu melalui sms, telepon ataupun melalui media social yang sudah di sediakan seperti; Facebook, Twitter, dll. kemudian kedua pendengar yang pasif, jumlahya tidak terbatas dan sulit untuk mendeteksi pendengar pasif karena mereka hanya mendengarkan dan tidak melakukan interaksi langsung dengan penyiar. Pendengar aktif maupun pasif atau yang biasa disebut fans merupakan pendukung yang besar bagi perkembangan suatu lembaga penyiaran/radio. Apabila sebuah radio siaran sudah mencapai target audiens dengan tepat dan benar, maka sejumlah kerjasama akan terjalin dengan para klien melalui periklanan yang mempercayainya sebagai media yang tepat untuk menyampaikan promosi sejumlah produk atau suatu acara (event). Radio juga dapat menjalin kerjasama bukan hanya periklanan tetapi melakukan suatu Dialog Interaktif atau Talkshow melalui Nota Kesepahaman (Memorandum of Understanding), misalnya menjalin kerjasama dengan Sekolah maupun Universitas.

Sebenarnya, tidaklah fair untuk membandingkan RRI sebagai lembaga penyiaran publik dengan lembaga penyiaran swasta karena keduanya membawa misi yang berbeda. Lembaga penyiaran publik seperti RRI tidak hanya sekedar memberikan hiburan kepada masyarakat, tapi yang lebih penting bahwa program-program berita, hiburan dan informasi yang disiarkannya harus memberikan "pencerahan" kepada masyarakat serta melayani kelompok-kelompok masyarakat yang beragam, bahkan kalangan minoritas. Oleh karena itu, kadang kala sebuah program siaran hanya didengarkan sedikit orang karena memang ditujukan untuk khalayak spesifik. Disisi lain, lembaga penyiaran swasta lebih mengedepankan usaha-usaha untuk mengejar keuntungan meskipun mereka bisa juga menyiarkan program-program yang mencerminkan layanan publik. Meskipun demikian, mencari keuntungan adalah motif utamanya. Oleh karena itu, memberikan hiburan akan lebih kuat dibandingkan memberikan program informasi yang "mencerahkan" sehingga akan jauh lebih diminati oleh khalayak. Meskipun demikian, memetakan persaingan semacam ini tetaplah penting bukan demi menunjukkan siapa yang paling difavoritkan dan tidak demi kepentingan iklan, tapi yang lebih penting apakah RRI masih relatif menarik bagi khalayak. Kedua, yang tidak kalah pentingnya bahwa masing-masing radio mempunyai gaya yang berbeda sehingga kecenderungan atas masing-masing gaya bisa diidentifikasi meskipun harus dilakukan penelitian lebih lanjut.

Kualitas pelayanan memiliki pengukuran kualitas yang merupakan peranan penting untuk menjaga keberlangsungan sebuah indutri, maka dari itu pengukuran kualitas dapat dilakukan pada industry manufaktur maupun jasa. Kualitas pelayanan yang baik akan menaikkan tingkat loyalitas seseorang pelanggan atau yang dalam penyiaran disebut pendengar. Siaran radio memilik dampak yang sangat luas bagi masyarakat, karena itu peranan perencanaan (Planning Programming), pembagian kerja, pengendalian, keterampilan dan koordinasi, menjadi sangat penting. Penyelenggaraan siaran merupakan kerja tim dan kolektif, maka diperlukan secara efektif dan efisien untuk menghasilkan output yang berkualitas.

Karakteristik responden adalah mendeskripsikan identitas dari responden sampel penelitian yang telah ditetapkan dengan tunjuan untuk memberikan gambaran yang menjadi sample dalam penelitian ini. Adapun responden dalam penelitian ini adalah Pendengar siaran radio RRI Makassar yang berjumlah 100 orang dari hasil perhitungan rumus slovin. Karakterstik responden yang dimasukan dalam penelitian ini antara lain jenis kelamin, usia, dan domisili. Untuk lebih memperjelas karakteristik responden yang dimaksud, maka disajikan dalam bentuk Tabel 2 sebagai berikut :

Tabel 2 Jenis Kelamin

\begin{tabular}{lccc}
\hline & Frequency & Valid (\%) & Cumulative (\%) \\
\hline Laki-Laki & 44 & 44.0 & 44.0 \\
Perempuan & 56 & 56.0 & 100.0 \\
\hline Total & 100 & 100 & \\
\hline Sumber: Hasil Identifikasi Responden, 2020
\end{tabular}

Berdasarkan Tabel 2 dapat diketahui bahwa dari jumlah responden 100 orang, didominasi oleh perempuan sebanyak 56 orang (44\%), dimana jumlah ini besar dibandingkan dengan responden laki - laki sebanyak 56 orang (56\%). Hal ini menunjukan bahwa mayoritas pendengar siaran radio RRI Makassar adalah jenis kelamin perempuan dikarenakan perempuan lebih banyak beraktifitas dirumah.

Tabel 3 Usia Responden

\begin{tabular}{lccc}
\hline & Frequency & Valid (\%) & Cumulative (\%) \\
\hline 15-29 tahun & 78 & 78.0 & 78.0 \\
30-39 tahun & 11 & 11.0 & 89.0 \\
$40-49$ tahun & 11 & 11.0 & 100 \\
\hline Total & 100 & 100 & \\
\hline Sumber: Hasil Identifikasi Responden, 2020
\end{tabular}

Berdasarkan Tabel 3 diketahui bahwa jumlah responden dalam penelitian ini didominasi oleh kalangan yang berusia lebih mudah dengan kisaran usia $15-29$ 
tahun yaitu sebanyak 78 orang dengan jumlah persentase $78 \%$ dari total keseluruhan responden. Kemudian, usia 30 - 39 tahun sebanyak 11 orang dengan persentase $11 \%$ dari jumlah keseluruhan responden. Sedangkan usia $40-$ 60 tahun sebanyak 11 orang juga. Hal ini menunjukan bahwa usia 15-29 tahun lebih sering mendengar siaran radio ketimbang usia $40-60$ tahun.

Tabel 4 Domisili

\begin{tabular}{lccc}
\hline & Frequency & Valid (\%) & Cumulative (\%) \\
\hline Makassar & 72 & 72.0 & 72.0 \\
Gowa & 11 & 11.0 & 83.0 \\
Takalar & 4 & 4.0 & 87.0 \\
Maros & 6 & 6.0 & 93.0 \\
Pangkep & 7 & 7.0 & 100.0 \\
\hline \multicolumn{1}{c}{ Total } & 100 & 100.0 & \\
\hline Sumber: Hasil Identifikasi Responden, 2020
\end{tabular}

Berdasarkan Tabel 4 diatas menunjukan bawaj responden yang sering mendengar siaran radio RRI makassar berasar dari Kota Makassar yaitu sebanyak 72 orang (72\%), sedangkannya selebihnya berasal dari Kabupaten Gowa 11 orang (11\%), Kabupaten Takalar 4 orang (4\%), Kabupaten Maros 6 orang (6\%), dan Kabupaten Pangkep sebanyak 7 orang (7\%). Hal ini menunjukan bahwa pendengar radio RRI Makassar dominan berasal dari kota Makassar juga.

Untuk mengetahui pengaruh Keandalan, daya tanggap, jaminan, empati dan bukti fisik, terhadap loyalitas pelanggan pada Lembaga Radio Republik Indonesia Makassar. Dimana dalam melakukan pengujian dalam penelitian ini maka digunakan analisis regresi linear berganda (multiplier regression), dengan menggunakan SPSS Release 24 yang dapat disajikan pada Tabel 5 berikut ini :

Tabel 5 Hasil Analisis Regresi Linear Berganda

\begin{tabular}{lccc}
\hline \multirow{2}{*}{ Model } & \multicolumn{2}{c}{$\begin{array}{c}\text { Unstandardized } \\
\text { Coefficients }\end{array}$} & $\begin{array}{c}\text { Standardized } \\
\text { Coefficients }\end{array}$ \\
\cline { 2 - 4 } & B & Std. Error & Beta \\
\hline A & 6,260 & 4,991 & \\
X1 & 1,137 &, 210 &, 304 \\
X2 & 1,106 &, 337 &, 331 \\
X3 & 1,064 &, 376 &, 319 \\
X4 & 1,510 &, 489 &, 277 \\
X5 & 1,814 &, 560 &, 318 \\
\hline
\end{tabular}

Sumber : Data diolah, 2020

Berdasarkan Tabel 5 di atas, maka nilai konstanta a $=6,260$ dan koefisien regresi $\mathrm{B} 1=1,137 ; \mathrm{B} 2=1,106 ; \mathrm{B} 3$ $=1,064 ; \mathrm{B} 4=1,510 ; \mathrm{B} 5=1,814 ; \mathrm{e}=5,653$, nilai konstanta dan koefisien regresi (a, B2, B3, B4, B5, e) ini dimasukan dalam persamaan regresi linear berganda berikut ini:

$\mathrm{Y}=6,260+1,137 \mathrm{X} 1+1,106 \mathrm{X} 2+1,064 \mathrm{X} 3+1,510 \mathrm{X} 4+1,814 \mathrm{X}$ $5+5,663$

Persamaan regresi tersebut dapat diinterpretasikan sebagai berikut :

a. Nilai konstantan regresi sebesar 6,260, menunjukkan bahwa pada keandalan, daya tanggap, jaminan, empati dan bukti fisik dengan kondisi konstan atau $\mathrm{X}=0$, maka pengaruh Terhadap Loyalitas Konsumen Radio Rebulik Indonesia Makassar sebesar 6,260.

b. X1 ( Keandalan) koefisien regresinya sebesar 1,137, mempunyai pengaruh positif terhadap Y (Loyalitas Konsumen). Artinya apabila keandalan semakin baik dengan asumsi variabel lain konstan, maka hal tersebut dapat meningkatkan pengaruh loyalitas Konsumen Radio Republik Indonesia Makassar sebesar 1,137

c. X2 (Daya Tanggap) koefisien regresinya sebesar 1,106, mempunyai pengaruh positif terhadap $\mathrm{Y}$ (Loyalitas Konsumen). Artinya apabila daya tanggap semakin baik dengan asumsi variabel lain konstan, maka hal tersebut dapat meningkatkan pengaruh loyalitas Konsumen Radio Republik Indonesia Makassar sebesar 1,106

d. X3 (Jaminan) koefisien regresinya sebesar 1,064, mempunyai pengaruh positif terhadap Y (Loyalitas Konsumen). Artinya apabila Jaminan semakin baik dengan asumsi variabel lain konstan, maka hal tersebut dapat meningkatkan pengaruh loyalitas Konsumen Radio Republik Indonesia Makassar sebesar 1,064

e. X4 (Empati) koefisien regresinya sebesar 1,510, mempunyai pengaruh positif terhadap Y (Loyalitas Konsumen). Artinya apabila empati semakin baik dengan asumsi variabel lain konstan, maka hal tersebut dapat meningkatkan pengaruh loyalitas Konsumen Radio Republik Indonesia Makassar sebesar 1,510

f. X2 (Bukti Fisik) koefisien regresinya sebesar 1,815, mempunyai pengaruh positif terhadap Y (Loyalitas Konsumen). Artinya apabila bukti fisik semakin baik dengan asumsi variabel lain konstan, maka hal tersebut dapat meningkatkan pengaruh loyalitas Konsumen Radio Republik Indonesia Makassar sebesar 1,815

Pengujian hipotesis dalam penelitian ini terbagi atas dua pengujian yakni Uji serempak (uji F) dan uji parsial (uji t), yang dapat diuraikan satu persatu yaitu :

a. Uji F

Pada tahapan ini akan diuji pengaruh variabel independent (keandalan, daya tanggap, jaminan, empati dan bukti fisik) terhadap variabel dependen (Loyalitas Konsumen) secara keseluruhan (simultan) yang dapat dilihat pada Tabel 6 berikut :

Tabel 6 Hasil Uji F

\begin{tabular}{lccccc}
\hline \multicolumn{6}{c}{ ANOVA $^{\text {a }}$} \\
\hline Model & $\begin{array}{c}\text { Sum of } \\
\text { Squares }\end{array}$ & df & $\begin{array}{c}\text { Mean } \\
\text { Square }\end{array}$ & F & Sig. \\
\hline Regression & 6352,455 & 5 & 1270,491 & 40,207 & $.000^{\text {b }}$ \\
\hline Residual & 2970,295 & 94 & 31,599 & & \\
\hline Total & 9322,750 & 99 & & & \\
\hline Sumber : Data diolah, 2020
\end{tabular}


Dari hasil analisis regresi dapat diketahui bahwa secara Bersama-sama (simultan) variabel independent memiliki pengaruh yang signifikan terhadap variabel dependen. Hal ini dapat dibuktikan dari nilai Fhitung sebesar 40,207 dengan nilai signifikansi (Sig) 0,000. Sedangkan Ftabel pada taraf signifikansi 5\% sebesar 2,31 sehingga dari hasil perhitungan tanpa bahwa Fhitung lebih besar dari Ftabel (40,207 > 2,31), sehingga Ho ditolak. Dengan demikian, maka model regresi dapat digunakan untuk memprediksi loyalitas konsumen atau dapat dikatakan bahwa keandalan, daya tanggap, jaminan, empati dan bukti fisik secara bersama-sama berpengaruh terhadap loyalitas konsumen Radio Republik Indonesia Makassar.

b. Uji T (Uji Parsial)

Selanjutnya untuk meyakinkan bahwa masingmasing variabel yaitu : keandalan, daya tanggap, jaminan, empati dan bukti fisik berpengaruh terhadap loyalitas konsumen akan dilakukan pengujian secara parsial. Dari perhitungan computer yang disajikan dalam tabel berikut :

Tabel 7 Hasil Uji T (Coefficients ${ }^{\mathrm{a}}$ )

\begin{tabular}{cccccc}
\hline \multicolumn{7}{c}{ Coefficients $^{\mathrm{a}}$} \\
\hline \multirow{2}{*}{ Model } & \multicolumn{2}{c}{$\begin{array}{c}\text { Unstandardized } \\
\text { Coefficients }\end{array}$} & $\begin{array}{c}\text { Standardized } \\
\text { Coefficients }\end{array}$ & & \multirow{2}{*}{ S } \\
\cline { 2 - 5 } & $\mathrm{B}$ & $\begin{array}{c}\text { Std. } \\
\text { Error }\end{array}$ & Beta & & \\
\hline $\mathrm{A}$ & 6,260 & 4,991 & & 5,653 &, 003 \\
\hline $\mathrm{X} 1$ & 1,137 &, 210 &, 304 & 3,652 &, 006 \\
\hline $\mathrm{X} 2$ & 1,106 &, 337 &, 331 & 4,282 &, 001 \\
\hline X3 & 1,064 &, 376 &, 319 & 2,169 &, 016 \\
\hline X4 & 1,510 &, 489 &, 277 & 2,311 &, 013 \\
\hline X5 & 1,814 &, 560 &, 318 & 3,237 &, 002 \\
\hline
\end{tabular}

Sumber : Data diolah, 2020

Uji t merupakan Pengujian koefisien regresi secara sendiri-sendiri.

1) Variabel Keandalan (X1)

Hipotesis : ada pengaruh yang signifikan secara positif antara variabel keandalan terhadap loyalitas Konsumen Radio Republik Indonesia Makassar.

Pengujian secara SPSS yaitu dengan melihat probabilitas signifikansi $(\mathrm{P}$-Value $)=0,006<0,05$ dan $\mathrm{T}$ hitung sebesar 3,652 dengan nilai $\mathrm{T}$ tabel yaitu 1,98 karena $\mathrm{T}$ hitung > T tabel, maka variabel keandalan (X1) berpengaruh positif dan signifikan terhadap loyalitas konsumen berarti Ho ditolak Ha diterima.

2) Variabel Daya Tanggap (X2)

Hipotesis : ada pengaruh yang signifikan secara positif antara variabel daya tanggap terhadap loyalitas Konsumen Radio Republik Indonesia Makassar. Pengujian secara SPSS yaitu dengan melihat probabilitas signifikansi $\quad(\mathrm{P}$-Value $)=$ $0,001<0,05$ dan $\mathrm{T}$ hitung sebesar 4,282 dengan nilai $\mathrm{T}$ tabel yaitu 1,98 karena $\mathrm{T}$ hitung $>\mathrm{T}$ tabel, maka variabel daya tanggap (X2) berpengaruh positif dan signifikan terhadap loyalitas konsumen berarti Ho ditolak Ha diterima.
3) Variabel Jaminan (X3)

Hipotesis : ada pengaruh yang signifikan secara positif antara variabel jaminan terhadap loyalitas Konsumen Radio Republik Indonesia Makassar. Pengujian secara SPSS yaitu dengan melihat probabilitas signifikansi $\quad(\mathrm{P}-$ Value $)=0,016<$ 0,05 dan $\mathrm{T}$ hitung sebesar 2,169 dengan nilai $\mathrm{T}$ tabel yaitu 1,98 karena $\mathrm{T}$ hitung $>\mathrm{T}$ tabel, maka variabel jaminan (X3) berpengaruh positif dan signifikan terhadap loyalitas konsumen berarti Ho ditolak Ha diterima.

4) Variabel Empati (X4)

Hipotesis : ada pengaruh yang signifikan secara positif antara variabel empati terhadap loyalitas Konsumen Radio Republik Indonesia Makassar. Pengujian secara SPSS yaitu dengan melihat probabilitas signifikansi $\quad(\mathrm{P}-$ Value $)=0,002<$ 0,05 dan $\mathrm{T}$ hitung sebesar 3,237 dengan nilai $\mathrm{T}$ tabel yaitu 1,98 karena $\mathrm{T}$ hitung $>\mathrm{T}$ tabel, maka variabel bukti fisik (X5) berpengaruh positif dan signifikan terhadap loyalitas konsumen berarti Ho ditolak Ha diterima.

5) Variabel Bukti Fisik (X5)

Hipotesis : ada pengaruh yang signifikan secara positif antara variabel bukti fisik terhadap loyalitas Konsumen Radio Republik Indonesia Makassar. Pengujian secara SPSS yaitu dengan melihat probabilitas signifikansi $\quad(\mathrm{P}-$ Value $)=0,016<$ 0,05 dan $\mathrm{T}$ hitung sebesar 2,169 dengan nilai $\mathrm{T}$ tabel yaitu 1,98 karena $\mathrm{T}$ hitung $>\mathrm{T}$ tabel, maka variabel keandalan (X3) berpengaruh positif dan signifikan terhadap loyalitas konsumen berarti Ho ditolak Ha diterima.

c. Koefisien Determinasi

Koefisien deterimasi digunakan untuk menghitung kontribusi variabel independent terhadap variabel dependen, dari hasil pengolahan SPSS diperoleh hasil sebagai berikut :

Tabel 8 Hasil Uji Koefisien Determinasi 3Hasil Nilai Adjusted R Square

\begin{tabular}{|c|c|c|c|c|}
\hline \multicolumn{5}{|c|}{ Model Summary } \\
\hline Model & $\mathrm{R}$ & R Square & $\begin{array}{l}\text { Adjusted } \\
\text { R Square }\end{array}$ & $\begin{array}{l}\text { Std. Error of } \\
\text { the Estimate }\end{array}$ \\
\hline 1 & $.825^{\mathrm{a}}$ & 881 & 864 & 7,621 \\
\hline
\end{tabular}

Dari Tabel 8 diketahui besarnya kontribusi variabel keandalan, daya tanggap, jaminan, empati, dan bukti fisik terhadap loyalitas konsumen Radio Radio Republik Indonesia Makassar dengan melihat hasil nilai adjusted $\mathrm{R}$ Squeare atau Adjusted Ra) $=0,864$ hal ini berarti bahwa variabel keandalan, daya tanggap, jaminan, empati, dan bukti fisik menjelaskan perubahan pada variabel loyalitas konsumen sebesar 86,4\% sedangkan sisanya yaitu 13,6\% dijelaskan oleh factor-faktor lain di luar variabel.

Hasil analisis regresi baik secara Bersama-sama maupun parsial antara variabel keandalan, daya tanggap, jaminan, empati, dan bukti fisik terhadap loyalitas Radio Republik Indonesia Makassar, sebagai berikut : 
a. Pengaruh keandalan terhadap loyalitas konsumen

Hasil uji statistic menunjukan bahwa koefisien regresi variabel keandalan yang dihasilkan sebesar 1,137, artinya jika keandalan meningkat maka akan meningkatkan loyalitas pendengar. Hasil ini juga didukung oleh nilai rata-rata dari distribusi jawaban responden atas pernyataan dari variabel keandalan sebesar 4,04. Besaran angkat tersebut menunjjukan bahwa ratarata responden setuju dengan pernyataan yang terkait keandalan RRI yang terdapat dalam 14 item pernyataan tersebut. Hasil temuan bahwa pendengar telah puas terhadap keandalan dari segi siaran RRI Makassar yang ditunjukan dalam bentuk ketepatan siaran, keakuratan informasi dan tepat waktu Ketika menyiaran program siaran. Sehingga dengan meningkatnya keandalan siaran RRI Makasssar akan mempengaruhi loyalitas pendengar. sehingga secara keseluruhan dari hasil penelitian ini bahwa keandalan yang diberikan kepada pendengar siaran Radio Republik Indonesai Kota Makassar berpengaruh meningkatkan loyalitas pendengar radio.

b. Pengaruh Daya Tanggap terhadap loyalitas

konsumen

Hasil uji statistik menunjukan bahwa koefisien regresi variabel Daya Tanggap yang dihasilkan sebesar 1,106, artinya jika Daya Tanggap meningkat maka akan meningkatkan loyalitas pendengar. Hasil ini juga didukung oleh nilai rata-rata dari distribusi jawaban responden atas pernyataan dari variabel Daya Tanggap sebesar 3,8. Besaran angka tersebut menunjukan bahwa rata-rata responden setuju dengan pernyataan yang terkait Daya Tanggap RRI yang terdapat dalam 6 item pernyataan tersebut. Artinya daya tanggap kepada pendengar merupakan bentuk layanan seperti menaggapi dan memberikan solusi Ketika terjadi permasalahan pada saat penyiaran maupun masalah-masalah yang disampaikan oleh pendengar radio. Serta kepedulian penyiar kepada pendengar Ketika pendengar menginginkan siaran yang sesuai dengan kebutuhan mereka sehingga secara keseluruhan dari hasil penelitian ini bahwa daya tanggap yang diberikan kepada pendengar siaran Radio Republik Indonesai Kota Makassar berpengaruh meningkatkan loyalitas pendengar radio.

c. Pengaruh Jaminan terhadap loyalitas konsumen

Hasil uji statistik menunjukan bahwa koefisien regresi variabel Jaminan yang dihasilkan sebesar 1,064, artinya jika Jaminan meningkat maka akan meningkatkan loyalitas pendengar. Hasil ini juga didukung oleh nilai rata-rata dari distribusi jawaban responden atas pernyataan dari variabel Jaminan sebesar 4,3. Besaran angka tersebut menunjukan bahwa rata-rata responden setuju dengan pernyataan yang terkait Jaminan RRI yang terdapat dalam 6 item pernyataan tersebut. Artinya jeminan yang telah diberikan oleh RRI Makassar telah memberikan kenyamanan dalam mendengar dan malayani para pendengar radio RRI Makassar sehingga secara keseluruhan dari hasil penelitian ini bahwa Jaminan yang diberikan kepada pendengar siaran Radio Republik Indonesai Kota Makassar berpengaruh meningkatkan loyalitas pendengar radio. d. Pengaruh Empati terhadap loyalitas konsumen

Hasil uji statistik menunjukan bahwa koefisien regresi variabel Empati yang dihasilkan sebesar 1,510, artinya jika Empati meningkat maka akan meningkatkan loyalitas pendengar. Hasil ini juga didukung oleh nilai rata-rata dari distribusi jawaban responden atas pernyataan dari variabel Empati sebesar 4. Besaran angka tersebut menunjukan bahwa rata-rata responden setuju dengan pernyataan yang terkait Empati RRI yang terdapat dalam 6 item pernyataan tersebut. Artinya empati yang diberikan kepada pendengar sudah baik. Penyiar ataupun RRI Makassar sudah peka terhadap keinginan dan kebutuhan pendengar sehingga secara keseluruhan dari hasil penelitian ini bahwa Empati yang diberikan kepada pendengar siaran Radio Republik Indonesai Kota Makassar berpengaruh meningkatkan loyalitas pendengar radio.

e. Pengaruh Bukti Fisik terhadap loyalitas konsumen

Hasil uji statistik menunjukan bahwa koefisien regresi variabel Bukti Fisik yang dihasilkan sebesar 1,814, artinya jika Bukti Fisik meningkat maka akan meningkatkan loyalitas pendengar. Hasil ini juga didukung oleh nilai rata-rata dari distribusi jawaban responden atas pernyataan dari variabel Bukti Fisik sebesar 3,9. Besaran angka tersebut menunjukan bahwa rata-rata responden setuju dengan pernyataan yang terkait Bukti Fisik RRI yang terdapat dalam 3 item pernyataan tersebut. bukti fisik dalam hal ini yang menunjang siaran RRI Makassar seperti alat pendukung penyiaran yang membuat frekuensi dan suara penyiar jelas Ketika didengar oleh pendengar sehingga secara keseluruhan dari hasil penelitian ini bahwa bukti fisik yang diberikan kepada pendengar siaran Radio Republik Indonesia Kota Makassar berpengaruh meningkatkan loyalitas pendengar radio.

f. Pengaruh keandalan, Daya Tanggap, Jaminan, Empati dan Bukti Fisik Terhadap Loyalitas Konsumen

Dari hasil penelitian yang dilakukan dengan pengujian parsial dan Bersama-sama dapat disimpulkan bahwa ke lima dimensi kualitas pelayanan mempunyai pengaruh yang signifikan terhadapa loyalitas konsumen Radio Republik Indonesia Makassar. Dengan demikian Hipotesis dalam penelitian ini diterima.

\section{SIMPULAN}

Hasil penelitian menyimpulkan bahwa dimensi loyalitas pelayanan berupa keandalan, daya tanggap, jaminan, empati dan bukti fisik memberikan dampak terhadap loyalitas konsumen radio Republik Indonesia Makassar. Untuk penelitian selanjutnya perlu memperhatikan aspek dimensi jaminan, instrument dari empati, kualitas pelayanan yang meliputi keandalan, daya tanggap, jaminan, empati dan bukti fisik. 


\section{DAFTAR PUSTAKA}

Darmawan. 2013. Metode Penelitian Kuantitatif. Bandung: Remaja Rosdakarya.

Fajar, A., Remmang, H. and Menne, F. 2020. Pengaruh Kompensasi, Disiplin Kerja Dan Lingkungan Kerja Terhadap Kinerja Pegawai Pada Pusat Pengembangan Sumber Daya Manusia Regional Makassar. Indonesian Journal of Business and Management. 2, 1 (Mar. 2020), 21-27.

Ghozali, Imam. 2018. Aplikasi Analisis Multivariate dengan Program IBM SPSS 25. Badan Penerbit Universitas Diponegoro: Semarang.

Giddens. 2002. Customer Loyalty : Menumbuhkan dan Mempertahankan Kesetiaan Pelanggan. Ahli Bahasa : Dwi Kartini Jaya. Edisi Revisi dan Terbaru. Jakarta : Erlangga

Sugiyono. 2012.Metode Penelitian Bisnis. Bandung : Alfabeta.

Sugiyono. 2013. Metode Penelitian Kuantitatif, Kualitatif dan R\&D. Bandung: Alfabeta.CV

Sugiyono. 2016. Metode Penelitian Kuantitatif, Kualitatif, R\&D. Bandung: IKAPI.

Tjiptono, Fandy. 2002. Strategi Pemasaran. Yogyakarta : Penerbit Andi. Eko, Widodo Suparno. 2015. Manajemen Pengembangan Sumber Daya Manusia.Yogyakarta: Pustaka Pelajar. 